\title{
Best Practices in Road Transport: An Exploratory Study
}

\author{
Mar Fernández Vázquez-NogueroliD, Iván González-Boubeta (iD, Pablo Dominguez-Caamaño (iD, \\ José Carlos Prado-PradoiD \\ Escuela de Ingeniería Industrial, Universidad de Vigo (Spain) \\ marfernandezvazquez@uvigo.es,ivangonzalezboubeta@uvigo.es,padominguez@uvigo.es,jcprado@uvigo.es
}

Received: November 2017

Accepted: January 2018

\begin{abstract}
:
Purpose: Road transport aspects are becoming increasingly important due to their high impact on economic, environmental and social sustainability. Considering the triple bottom line approach, best practices play a fundamental role within organisations. The purpose of this paper is to analyse several sustainable initiatives in road transport adopted by companies.

Design/methodology/approach: The findings were developed and evaluated based on empirical data captured through a survey of 98 professionals involved in logistics and transport activities. Additionally, key literature on transport initiatives was reviewed to supplement the framework for the implementation of best practices in road transport.
\end{abstract}

Findings: The exploratory study shows the importance of each best practice and determines the level of implementation of each initiative, comparing the results among different dealers (retailers, wholesalers, carriers and manufacturers), type of transport fleet and companies' revenues.

Research limitations/implications: The sample of 98 companies was based on simple search filters and the group is not wholly representative of all sectors. Respondents were mainly managers from Spain involved in logistics and transport activities. Surveyed companies included manufacturing, retailers, wholesalers and third-party logistics providers.

Practical implications: The most common best practices in road transport are identified, including initiatives related to: efficiency, reusability, safety, optimization, emissions, waste and recycling. Initiatives that influence road transport are ranked by their degree of implementation in the companies analysed.

Social implications: Implementation of some of these best practices may help lessen negative impacts of road transport on society and the environment.

Originality/value: The study results indicate which practices are most frequently used and their level of implementation depending on companies' roles in the supply chain, revenues and types of transport fleet. By implementing the proposed best practices, companies will adopt sustainable behaviors to improve their transport performance.

Keywords: sustainability, road transport, best practices, supply chain, logistics 


\section{Introduction}

The emergence of the global economy and intensified competition among companies have led organisations to recognize the importance of improving supply chain management to maintain a dominant position in the market. In this context, the growing cost of materials, especially oil related, is of great importance, as it represents a significant source of expenditure for companies. In addition, these expenses increased due to the fact that the number of goods consumed in remote areas is increasing. Therefore, companies have been forced to implement a management approach based on waste elimination along the whole supply chain (Canali, Amani, Aramyan, Gheoldus, Moates, Östergren et al., 2016; Wee \& Wu, 2009). This assortment of management techniques is often related to the concept of "Lean Management", widely discussed in literature. Parallel to these techniques, society also demands changes from companies in social and environmental terms. For this reason, the concept of sustainability is commonly reviewed in literature and its importance is beyond doubt. Elkington's definition of sustainability (Eklington, 1998) provides a triple bottom line approach, including an economic, an environmental and a social dimension of this concept. According to this author, the three concepts must be considered to be able to meet the requirements and concerns of contemporary society. In this regard, some studies show how social and environmental initiatives may cause a significant positive impact on the economic level (Carter \& Rogers, 2008; Oberhofer \& Dieplinger, 2014). For this reason, both concepts "Lean Management" and "sustainability" can and should be fully complementary (Fercoq, Lamouri \& Carbone, 2016; García-Arca, González-Portela-Garrido \& Prado-Prado, 2017a; García-Arca, González-Portela-Garrido \& Prado-Prado, 2017b; Ho, 2010).

In spite of the importance of the integral vision of sustainability, theory and practice do not seem to conceive it in the same way. On the one hand, literature has mainly focused its attention on environmental sustainability practices (Domínguez-Caamaño, Olmedo, Rodríguez-García \& Prado-Prado, 2017; Porter \& Kramer, 2006). Thus, economic and social sustainability are concepts rarely discussed in recent literature, especially from a practical point of view. On the other hand, organisations have been able to incorporate the triple bottom line approach into corporate social responsibility practices (Basovníková, Abramuszkinová \& Vavřina, 2013; Huber, Nerudová \& Rozmahel, 2015). Furthermore, some authors state that several companies are focused on implementing environmental and social practices connected and aligned with the main economic objective (Matopoulos \& Bourlakis, 2010; Piotrowicz \& Cuthbertson, 2015). In this regard, there is a difference between practices that companies and researchers perceive as the most effective ones.

Several authors (De Gruyter, Currie \& Rose, 2016; Kolosz \& Grant-Muller, 2016) have focused their sustainability studies on transport processes owing to its impact on today's world. According to the United Nations Conference on Trade and Development (UNCTAD), sustainable freight transport systems entail, among other features, "the ability to provide transportation that is safe, socially inclusive, accessible, reliable, affordable, fuel-efficient, environmentally friendly, low-carbon, and resilient to shocks and disruptions, including those caused by climate change and natural disasters" (UNCTAD, 2015). It can be seen that several terms included in this definition are closely related to the triple bottom line approach. In the process of searching for a more sustainable transport model, best practices related to road transport have a vital role. This is due to the fact that road transport is the most common transport mode. According to EUROSTAT, almost $50 \%$ of the ton-kilometers transported within the EU in 2014 were transported by road (EUROSTAT, 2016). This information leads us to believe that sustainable initiatives in this area are relevant. In spite of the importance of best practices in road transport, we are not aware of any empirical study in literature that indicates which sustainable initiatives companies adopt most frequently. This gap is even more critical if we consider the limited approach provided by literature in economic and social sustainability practices.

The aim of this study is to determine the main best practices in road transport sustainability adopted by practitioners. Data captured from manufacturing, transport, wholesale and retail companies will be analysed separately with the intention of meeting the preferences of each role in the supply chain. Meanwhile, results on the implementation of best practices will be screened according to the companies' revenues and the transport fleet, so it represents a starting point for any professional who wants to improve the sustainability of the company. In order to achieve this goal, an exploratory study is carried out. This research is based on empirical data captured through a survey among Spanish companies of different sectors. 


\section{Methodology}

The present empirical study is part of a more extended study about road transport performance and its measurement. The whole study was carried out using a general methodology adapted from the books Research methodologies in Supply Chain Management (Kotzab, Seuring, Müller \& Reiner, 2005) and Business Research Methods (Bryman \& Bell, 2015). From these reviews, a set of data collection models was revised in order to determine the most appropriate. Finally, web survey was identified as the most adequate methodology because of its numerous advantages. According to Grant, Teller and Teller (2005), this is the best way to obtain complete data when compared to traditional methods. In addition, the processing time of the information collected through questionnaires drops drastically, but this alternative might be more expensive due to licenses required from web platforms. In the same article, it is concluded that e-mail notification and the attractiveness of incentives offered for participation are of importance to respondents.

The survey was structured in a mixed way, combining rating scale and dichotomous questions (yes/no). Moreover, some open questions were included to increase the information obtained, which resulted in a greater effort to process the results. Previously, in order to know the most common initiatives in road transport, a selection has been created based on a wide literature review on road transport best practices (Domínguez-Caamaño et al., 2017). As discussed above, recent literature only focuses its attention on environmental issues. Since the aim of the present study is to cover all the sustainability areas defined by Eklington (1998), some best practices were added by professional workers who have experience in supply chain management. Dichotomous questions were chosen to ask the use of these best practices. To increase our understanding of the context, we asked about the respondent's position and the main activity, sector, revenue and transport fleet of their companies (Kotzab, 2005). The first version of the questionnaire was reviewed and tested by academics. The aim of the test was to certify the quality of the survey.

To establish the universe of the study, we used the business database SABI. This economic and financial database contains information about more than one million Spanish companies, including companies' annual accounts. The search, which has a multi-sectorial approach, was aimed at including companies throughout the supply chain different areas. On the basis of the available data, 3,100 questionnaires were sent by email to the companies, together with a covering letter that explained the purpose of the study. Also, we let companies know that, upon completion of the study, results would be sent to the respondents, as Grant et al. (2005) suggested in their study. A total of 75 questionnaires were returned, but 14 of them were not useable because of the significant missing data. In furtherance of obtaining a larger sample, 63 of the most relevant companies that had not replied to our email were noticed by phone call, of which 44 were willing to complete the survey, but only 37 answered the questionnaire. In total 98 questionnaires were correctly completed. For the information gathering process, we used an electronic form created in the e-survey web-platform (http://www.e-encuesta.com/). The research took place during the last eight months of 2016.

\section{Respondents and their Organisations}

An empirical study was carried out to achieve the purposes outlined. Following the methodology defined, this section aims to capture contextual information about respondents and their companies. The final sample is made up of numerous companies of different sectors and roles in the supply chain. Figure 1 below shows the sample distribution.

The significant variety of sector contributed to give a multisector and global character to the study. Based on data in the Figure 1, the most common core activity was manufacturing. As transport activities are currently split into different departments, workers were asked about their role within the organisation. Most of them held supply chain managerial positions (over 49\%). The second largest group was Supply Chain Engineers (almost 34\%), followed by the contribution of other managers (over 12\%). The remaining respondents were CEOs (5\%), whose general visions enriched the results. Also, with the intention of knowing the average level of work experience of the respondents, they were questioned about the number of years they had been working in the same area. The average work experience was 12 years. Moreover, considering the high staff level of the respondents, it might be concluded that the group of respondents was made up of a solid staff of experts. In order to gain more knowledge about the 
logistics of the company, we asked companies which type of transport fleet they operated. Respondents had to indicate whether the fleet was insourced, outsourced to third-party logistics provider or composed of owner operators. Results can be observed in Figure 2, together with information about companies' revenues.
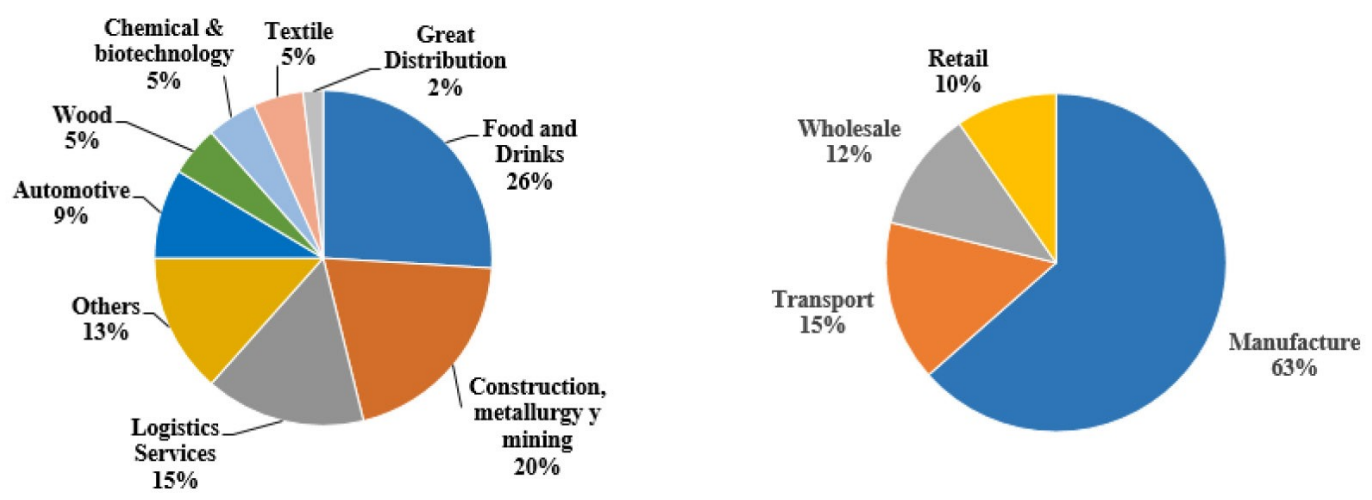

Figure 1. Companies by main sector and role in the supply chain
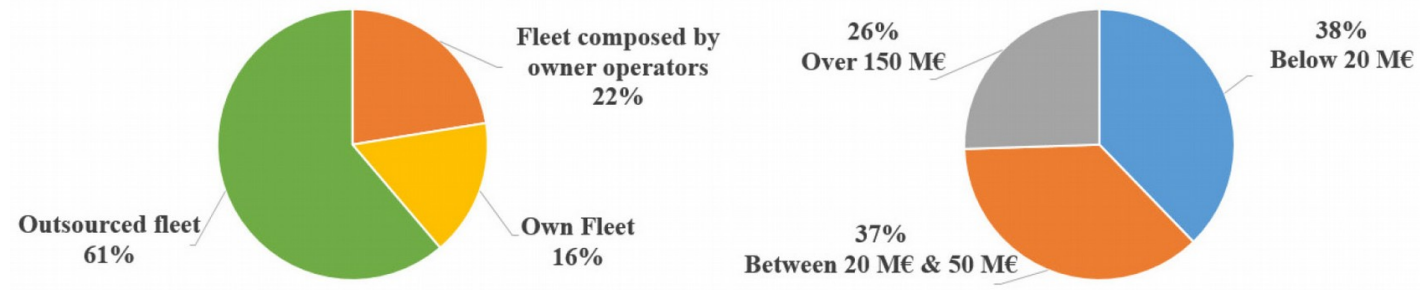

Figure 2. Companies by type of transport fleet and revenue

According to the data in Figure 2.61\% of respondents claimed to have outsourced their transport and over 20\% had a fleet of owner operators, being the smallest group represented by the companies with their own transport fleet $(16 \%)$. Regarding companies' economic performances, the majority of companies had revenues below $€ 20$ million (over $38 \%$ ), while only $26 \%$ of the companies had turnovers over $€ 150$ million. This enhances the fact that our sample is varied.

\section{Results}

\subsection{Adoption of Best Practices in Road Transport}

According to the best practices considered in the study, the level of implementation has been attained. These results can be observed in Figure 3.

Findings from the questionnaire show the percent of respondents who claim to have implemented each practice. Surprisingly, none of these best practices is implemented in even half of the companies surveyed. Both, Give a time slot to order loading and unloading and Packaging redesign, were listed as the most common approaches (49\% of respondents claimed to use it). These approaches might be popular because they are not subjected to economic investments and make logistics management easier. Nevertheless, its implementation might increase the current cost. Use of computer tools for route optimization was rated as the third most common initiative, which is usually related with the next practice Use of fleet management software. These results are not surprising considering the present importance of the route schedule (Sedghi, Ahmadian \& Aliakbar-Golkar, 2016). Use of reusable transport items is currently generating conflict among logistics practitioners, so this disagreement may have affected the achieved results. According to Pålsson, Finnsgård and Wänström (2013), it is necessary to consider the particular packaging system and the supply chain in which it is used. As regards, Making shared shipments, which ease optimization of resources, $36 \%$ of companies carry it out with non-competing companies while $17 \%$ do it with competing companies. According to some authors (Morali \& Searcy, 2013), these practices help increase the triple bottom line 
results. In addition, it can be noticed that some best practices directly related to environmental aspects, like Use of biofuels or other alternative fuels and Promoting the use of eco-driving, were implemented on less than $24 \%$ of companies. As mentioned before, the results show disconnection between what literature and companies identify as the most important sustainability practices.

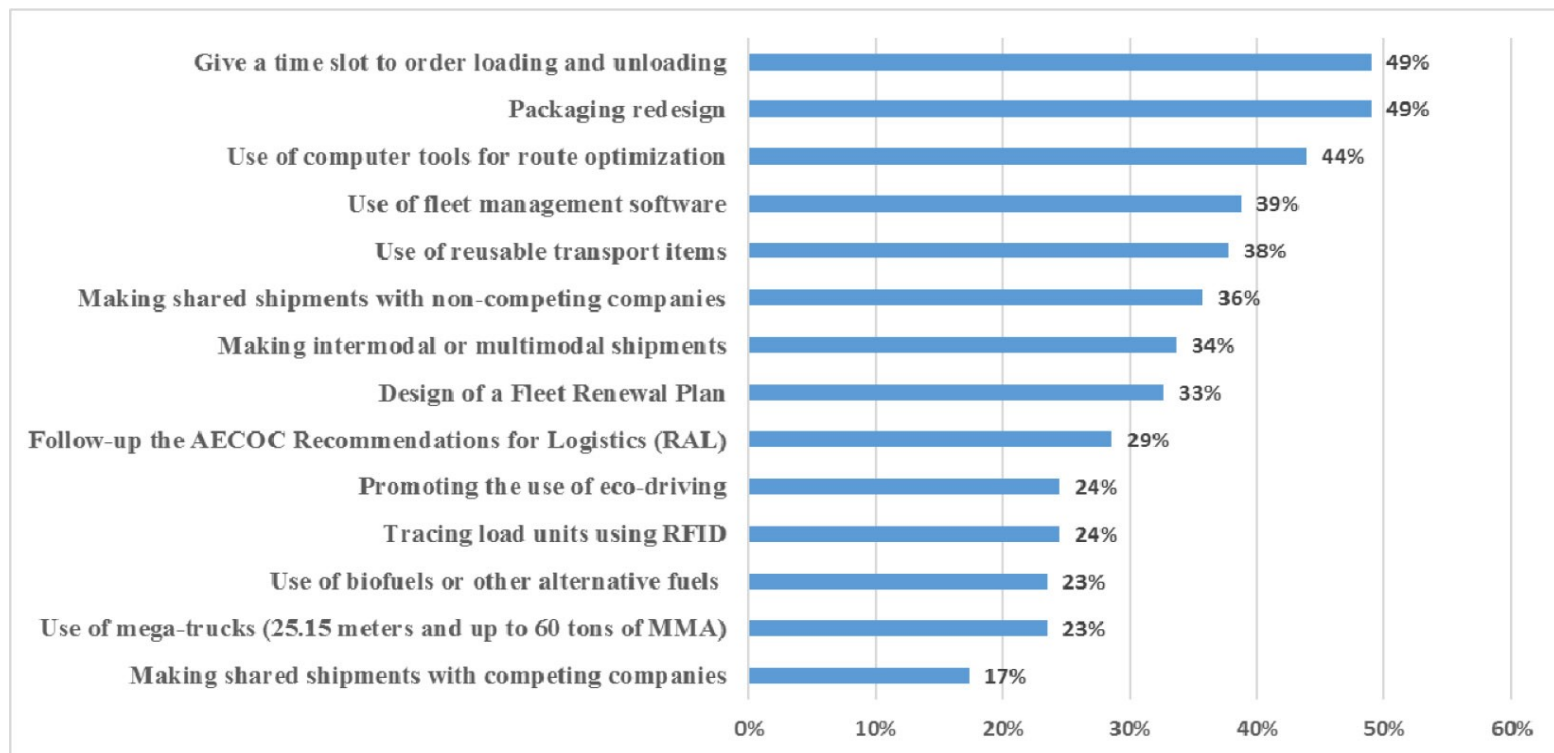

Figure 3. Best practices sorted by use

\subsection{Use of Best Practices by Companies' Roles in the Supply Chain}

In this section, best practices are classified according to companies' roles in the supply chain. The achieved results are shown in Table 1 below.

\begin{tabular}{|c|c|c|c|c|}
\hline Best practice & Manufacture & Transport & Wholesale & Retail \\
\hline Give a time slot to order loading and unloading & $51 \%$ & $44 \%$ & $50 \%$ & $45 \%$ \\
\hline Packaging redesign & $51 \%$ & $50 \%$ & $50 \%$ & $36 \%$ \\
\hline Use of computer tools for route optimization & $36 \%$ & $63 \%$ & $75 \%$ & $27 \%$ \\
\hline Use of fleet management software & $34 \%$ & $56 \%$ & $42 \%$ & $36 \%$ \\
\hline Use of reusable transport items & $36 \%$ & $31 \%$ & $33 \%$ & $64 \%$ \\
\hline Making shared shipments with non-competing companies & $34 \%$ & $44 \%$ & $33 \%$ & $36 \%$ \\
\hline Making intermodal or multimodal shipments & $37 \%$ & $25 \%$ & $25 \%$ & $36 \%$ \\
\hline Design of a Fleet Renewal Plan & $20 \%$ & $56 \%$ & $50 \%$ & $45 \%$ \\
\hline Follow-up the AECOC Recommendations for Logistics (RAL) & $27 \%$ & $38 \%$ & $25 \%$ & $27 \%$ \\
\hline Promoting the use of eco-driving & $22 \%$ & $31 \%$ & $25 \%$ & $27 \%$ \\
\hline Tracing load units using RFID & $20 \%$ & $31 \%$ & $25 \%$ & $36 \%$ \\
\hline Use of biofuels or other alternative fuels & $24 \%$ & $25 \%$ & $17 \%$ & $27 \%$ \\
\hline Use of mega-trucks (25.15 meters and up to 60 tons of MMA) & $22 \%$ & $13 \%$ & $42 \%$ & $27 \%$ \\
\hline Making shared shipments with competing companies & $17 \%$ & $19 \%$ & $17 \%$ & $18 \%$ \\
\hline
\end{tabular}

Table 1. Use of best practices by companies' roles in the supply chain 
As we can see in Table 1, the results for manufacturing companies are very similar to global results in terms of the use of best practices. This is due to the fact that manufacturing companies is the largest group within the sample (63\%). Thus, Give a time slot to order loading and unloading and Packeaging redesign are the most common practices for this kind of companies (over 50\%). Nevertheless, this disaggregation by companies' roles in the supply chain shows some surprising results for the other groups. In wholesalers' case, it stands out the high percentage obtained in Use of computer tools for route optimization $(75 \%)$ and Use of mega-trucks (42\%). These high values suggest how important is for wholesalers to minimize the distance traveled and the total number of trips. When analyzing the results obtained for retailers, other best practices stand out. Use of reusable transport items $(64 \%)$ and Tracing load units using RFID (36\%) have very high values compared to other surveyed groups. The reason for this fact might be an important concern about the tracking of load unit, especially in contrast to wholesalers. When compared to other groups, the little use of Packaging redesign (36\%) in the retail industry is also notable. According to Oglethorpe and Heron (2010), this might be due to the fact that packaging reduction might minimize product safety, increasing the probability of damage and decreasing product returns. Transport companies' opinion is very representative because of its expert profile. This group considers as the most usable best practices: Use of computer tools for route optimization (63\%), Use of fleet management software (56\%) and Design of a Fleet Renewal Plan (56\%). It might be noticed that these initiatives are strongly linked to resource management and distance traveled optimization. These results are in accordance with the ones obtained by Gupta, Singh and Suri (2015) who identified these practices as some of the most commonly used by logistics services providers (LSP). Follow-up the AECOC Recommendations for Logistics (38\%) can be observed in Table 1 that also has a high level of implementation compared to other groups.

\subsection{Use of Best Practices by Type of Transport Fleet}

After an analysis of companies' roles, the most implemented sustainable initiatives have been classified depending on the type of transport fleet operated by the companies. The respondents had to answer if either the fleet was composed of owner operators, insourced or outsourced to third-party logistics provider. A fleet composed of owner operators is formed either by truck drivers working full-time for the company, a figure that in Spain is known as an economically dependent self-employed worker, or by truckers who work for several companies and promote shared shipments. As regards insourced and outsourced transport fleets, companies with their own transport fleet employ truck drivers that work full-time for the company. Instead, other companies outsource their transport services to third-party logistics providers, which is known as an outsourced fleet. Table 2 shows the level of implementation of the different best practices according to the type of fleet operated by the respondents' companies.

Regarding Figure 2, companies with a fleet outsourced to third-party logistics provider are the largest group within the sample (61\%). Surprisingly, as we can see in Table 2, only two best practices are implemented in over half of the companies. These initiatives are: Give a time slot to order loading and unloading, which has been implemented by $52 \%$ of them, and Packaging redesign (53\%). Research by van Loon, Deketele, Dewaele, McKinnon and Rutherford (2015), explained in their article that packaging plays a key role in transportation efficiency, since its design affects trucks' loading capacity. Furthermore, Making shared shipments with non-competing companies (40\%) stands out among the others surveyed groups. The reason for this might be the existence of an important concern about optimizing trucks occupation.

Results for companies with fleets composed of owner operators show that the Use of computer tools for route optimization and the Design of a Fleet Renewal Plan are the most commonly used best practices. Some authors state the importance of purchasing trucks equipped with the newest technology in order to reduce environmental impact and empty travels (Mangiaracina, Marchet, Perotti, \& Tumino, 2015; McKinnon \& Ge, 2006). In companies with this type of fleet, Making shared shipments with competing companies has a low level of implementation. When compared to other groups, this initiative is also noteworthy. According to some authors (McKinnon, 2009; Wang, Sanchez Rodrigues \& Evans, 2015), obstructions like fear of sharing sensitive information and the compatibility of transport vehicles, prevent companies from its implementation. Nonetheless, despite these collaboration barriers, there are successful case studies about collaboration with competitors (Baranchenko \& Oglethorpe, 2012; Evangelista, 2014). 


\begin{tabular}{|c|c|c|c|}
\hline Best practice & $\begin{array}{l}\text { Fleet composed } \\
\text { of owner operators }\end{array}$ & Insourced & $\begin{array}{l}\text { Outsourced } \\
\text { fleet }\end{array}$ \\
\hline Give a time slot to order loading and unloading & $32 \%$ & $63 \%$ & $52 \%$ \\
\hline Packaging redesign & $41 \%$ & $44 \%$ & $53 \%$ \\
\hline Use of computer tools for route optimization & $55 \%$ & $63 \%$ & $35 \%$ \\
\hline Use of fleet management software & $27 \%$ & $69 \%$ & $35 \%$ \\
\hline Use of reusable transport items & $36 \%$ & $56 \%$ & $33 \%$ \\
\hline Making shared shipments with non-competing companies & $27 \%$ & $31 \%$ & $40 \%$ \\
\hline Making intermodal or multimodal shipments & $32 \%$ & $31 \%$ & $35 \%$ \\
\hline Design of a Fleet Renewal Plan & $55 \%$ & $50 \%$ & $20 \%$ \\
\hline Follow-up the AECOC Recommendations for Logistics (RAL) & $36 \%$ & $25 \%$ & $27 \%$ \\
\hline Promoting the use of eco-driving & $27 \%$ & $50 \%$ & $17 \%$ \\
\hline Tracing load units using RFID & $14 \%$ & $38 \%$ & $25 \%$ \\
\hline Use of biofuels or other alternative fuels & $23 \%$ & $31 \%$ & $22 \%$ \\
\hline Use of mega-trucks (25.15 meters and up to 60 tons of MMA) & $14 \%$ & $38 \%$ & $23 \%$ \\
\hline Making shared shipments with competing companies & $9 \%$ & $31 \%$ & $17 \%$ \\
\hline
\end{tabular}

Table 2. Use of best practices by type of fleet

Finally, in the case of companies with insourced fleets, it is worth stressing that six best practices are implemented in over half of the companies. The Use of fleet management software (69\%) is listed as the most common best practice and it is usually related with the next practice Use of computer tools for route optimization (63\%). According to Suzuki and Kabir (2015), these initiatives tend to reduce fuel costs and CO2 emissions, while extending the service life of the road infrastructure. With regard to Give a time slot to order loading and unloading (63\%) also has a high level of implementation among companies, which makes complete sense as time windows may have a significant impact on freight distribution costs (Defloiro, Gonzales-Feliu, Perboli \& Tadei, 2012). Promoting the use of eco-driving was rated as the fifth most common initiative, implemented in more than $50 \%$ of the companies; much more than for any other surveyed group (27\% and $17 \%$ for companies with owner operators fleets and outsourced fleets respectively). The reason for this might be the importance of controlling drivers' behavior to avoid errors such as excessive speed, excessive revolutions per minute and excessive idle time (Díaz-Ramirez, Giraldo-Peralta, Flórez-Ceron, Rangel, Mejía-Argueta, Huertas et al., 2017). Especially in freight transport, environmentally friendly driving might reduce fuel consumption up to 10\% (Kudla \& Klaas-Wissing, 2012). In general, companies with insourced fleets present high levels of implementation, with an average level of $45 \%$, compared with an average of $31 \%$ for both other surveyed groups. The results show how important these initiatives are for companies that manage their own fleets.

\subsection{Use of Best Practices by Companies' Revenues}

In the following section, the best practices are classified according to companies' economic performances. Three groups of respondents were defined distinguishing between companies with revenues below $€ 20$ million, between $€ 20$ million and $€ 150$ million and over $€ 150$ million. The percentage of companies, classified by revenues, who claimed to have implemented each practice are shown in Table 3.

Results of the analysis are striking regarding companies with revenues below $€ 20$ million, since none of the best practices was implemented in more than $40 \%$ of the companies. Furthermore, the really low level of implementation of Tracing load units using RFID (11\%) is understandable as the use of this technology requires an initial investment that many small and medium-sized enterprises cannot afford. Conversely, in the case of companies that had revenues between $€ 20$ million and $€ 150$ million, Tracing load units using RFID (36\%) was found to be the most implemented best practice compared with other surveyed groups. Regarding RFID, research by Bhero and Hoffman (2013) identifies the inefficiencies when implementing this technology in road freight transport 
activities, which helps understand its low level of acceptance. Again, when comparing companies with midrange revenues with other groups, the high level of implementation of Follow-up the AECOC Recommendations for Logistics (39\%) should also be highlighted due to its importance, regarding supply chain management (García-Arca, Prado-Prado \& González-Portela-Garrido, 2017).

\begin{tabular}{|c|c|c|c|}
\hline Best practice & $\begin{array}{c}\text { Below €20 } \\
\text { million }\end{array}$ & $\begin{array}{c}\text { Between €20 } \\
\text { million \& } € 150 \\
\text { million }\end{array}$ & $\begin{array}{c}\text { Over €150 } \\
\text { million }\end{array}$ \\
\hline Give a time slot to order loading and unloading & $38 \%$ & $53 \%$ & $60 \%$ \\
\hline Packaging redesign & $38 \%$ & $56 \%$ & $56 \%$ \\
\hline Use of computer tools for route optimization & $38 \%$ & $39 \%$ & $60 \%$ \\
\hline Use of fleet management software & $30 \%$ & $42 \%$ & $48 \%$ \\
\hline Use of reusable transport items & $24 \%$ & $33 \%$ & $64 \%$ \\
\hline Making shared shipments with non-competing companies & $32 \%$ & $36 \%$ & $40 \%$ \\
\hline Making intermodal or multimodal shipments & $27 \%$ & $36 \%$ & $40 \%$ \\
\hline Design of a Fleet Renewal Plan & $35 \%$ & $31 \%$ & $32 \%$ \\
\hline Follow-up the AECOC Recommendations for Logistics (RAL) & $24 \%$ & $39 \%$ & $20 \%$ \\
\hline Promoting the use of eco-driving & $22 \%$ & $25 \%$ & $28 \%$ \\
\hline Tracing load units using RFID & $11 \%$ & $36 \%$ & $28 \%$ \\
\hline Use of biofuels or other alternative fuels & $22 \%$ & $19 \%$ & $32 \%$ \\
\hline Use of mega-trucks ( 25.15 meters and up to 60 tons of MMA) & $27 \%$ & $17 \%$ & $28 \%$ \\
\hline Making shared shipments with competing companies & $16 \%$ & $19 \%$ & $16 \%$ \\
\hline
\end{tabular}

Table 3. Use of best practices by companies' revenues

The majority of the most implemented practices in companies with revenues over $€ 150$ million concur with the other groups: Give a time slot to order loading and unloading, Packaging redesign, Use of computer tools for route optimization and Use of fleet management software; being the Use of reusable transport items the only exception since it is the most implemented practice among high-revenue companies, but unpopular among the other groups. Our results show that, in general, the higher the companies' revenues are, the higher the level of implementation of best practices is. In most cases, economies of scale are the most likely reason for this. For example, the implementation of Give a time slot to order loading and unloading increases significantly when companies' billing increases, which might be due to the fact that companies with large revenues have greater bargaining power compared with small and medium-sized enterprises. Also, Use of computer tools for route optimization and Use of fleet management software are more implemented in companies with revenues over $€ 150$ million, as these enterprises tend to have larger fleets that are harder to manage and the money required to invest in expensive software tools. When companies try to reduce their costs, the Use of reusable transport items plays a fundamental role. The use of this best practice requires high investments, so companies with high revenues tend to have more deployment facilities. Research by van Loon et al. (2015) illustrated that packaging also might account for a significant portion of the greenhouse gas emissions. Finally, Making intermodal or multimodal shipments stands out against other surveyed groups. In this regard, some studies show how intermodality might be a good option for increasing efficiency, since rail and maritime transport are usually more energy efficient than road transport (Iannone, 2012; Mohammadi, Torabi, \& Tavakkoli-Moghaddam, 2014).

As it can be seen above, the results of the study show that the most common best practices are those whose implementation increases as companies' revenues raise. This corroborates the importance of the three pillars of sustainability. Likewise, the Use of biofuels or other alternative fuels is quite implemented in companies with high revenues. We believe that this initiative will become more popular over the next few years because the latest available data from the EU shows that biofuels consumption in the European Union keeps increasing 
(EurObserv'ER, 2017). However, several practices such as Making shared shipments with competing companies do not increase their level of implementation as companies' revenues increase. This result is not surprising considering that companies with high revenues often operate larger fleets that allow them to optimize trucks' occupation, therefore sharing information about their shipments with competitors means taking too much risk for too little reward. Nonetheless, according to Colicchia, Marchet, Melacini and Perotti (2013), there is a growing interest in literature about collaboration throughout the supply chain, with both customers and suppliers. This gives more weight to the fact that there is a shortage of real and effective collaborative actions that improve companies' environmental sustainability.

\section{Conclusions}

In this empirical study, the level of implementation among practitioners of some of the most common sustainable best practices in road transport has been shown. Global results demonstrate that not all best practices are equally used among companies. On the one hand, the most implemented best practices are related to packaging and implementation of software for route optimization and fleet management. On the other hand, diverse categories of best practices do not have sufficient implementation cases in the business context such as: collaboration with competing companies, use of mega-trucks and use of biofuels or other alternative fuels.

In addition, the level of implementation of each sustainable practice varies significantly depending on the companies' roles in the supply chain. In the case of manufacturing companies, practices about packaging redesign and about give time slots should be highlighted. Transport enterprises have focused on the use of software for route optimization and fleet management. Likewise, wholesalers have implemented these same tools and have designed fleet renewal plans. The use of reusable transport items and RFID are mostly implemented in retailers. Regarding results about the implementation of best practices according to the type of transport fleet, more than half of the companies surveyed that operate their own transport fleets have implemented at least six best practices, being the most outstanding group among the different clusters created. When it comes to the economic performance of the companies, the results of the study show that, in general, the most common best practices among all groups are those whose implementation increases as companies' revenues increase. These findings have some implications for practitioners. Based on the information provided, companies could focus their efforts on adopting the sustainable practices that are most commonly used in their supply chain roles and models. Based on the wide literature review on road transport best practices illustrated by Dominguez et al. (2017), it seems to exist a great difference between sustainable practices that companies and literature perceive as the most important ones.

Even though the disaggregation by roles, type of fleet and revenue has allowed us to obtain some remarkable results, we are aware that our study has some limitations. On the one hand, the sample of 98 companies was based on simple search filters and the group does not include all economic sectors. On the other hand, respondents were mainly managers from Spain involved in logistics and transport activities. It is necessary to take both limitations into account for further research in this field. Future research might focus on conducting case studies or action research where some of these initiatives are applied. Also, evaluating the usefulness and profitability of some of the best practices presented in this article might be another important line of research on sustainability.

\section{Declaration of Conflicting Interests}

The authors declared no potential conflicts of interest with respect to the research, authorship, and/or publication of this article.

\section{Funding}

The authors received no financial support for the research, authorship, and/or publication of this article.

\section{References}

Baranchenko, Y., \& Oglethorpe, D. (2012). The Potential Environmental Benefits of Co-Operative Businesses Within the Climate Change Agenda. Business Strategy and the Environment, 21(3), 197-210.

https://doi.org/10.1002/bse.733 
Basovníková, M., Abramuszkinová Pavlíková, E., \& Vavřina, J. (2013). Economic performance of Czech business entities in the context of CSRs' implementation. Acta Universitatis Agriculturae et Silviculturae Mendelianae Brunensis, 61(7), 1985-1994. https://doi.org/10.11118/actaun201361071985

Bhero, E., \& Hoffman, A. (2013,). Applying RFID technology to improve efficiency in border-post cargo clearance process. In Information Science, Computing and Telecommunications (PACT), 2013 Pan African International Conference on (137-141). IEEE. https://doi.org/10.1109/SCAT.2013.7055105

Bryman, A., \& Bell, E. (2015). Business research methods. USA: Oxford University Press.

Canali, M., Amani, P., Aramyan, L., Gheoldus, M., Moates, G., Östergren, K. et al. (2016). Food waste drivers in Europe, from identification to possible interventions. Sustainability, 9(1), 37. https://doi.org/10.3390/su9010037

Carter, C.R., \& Rogers, D.S. (2008). A framework of sustainable supply chain management: moving toward new theory. International journal of physical distribution \& logistics management, 38(5), 360-387. https://doi.org/10.1108/09600030810882816

Colicchia, C., Marchet, G., Melacini, M., \& Perotti, S. (2013). Building environmental sustainability: empirical evidence from Logistics Service Providers. Journal of Cleaner Production, 59, 197-209.

https://doi.org/10.1016/j.jclepro.2013.06.057

Deflorio, F.P., Gonzalez-Feliu, J., Perboli, G., \& Tadei, R. (2012). The influence of time windows on the costs of urban freight distribution services in city logistics applications. European Journal of Transport and Infrastructure Research, 12(3), 256-274. https://hal.archives-ouvertes.fr/halshs-00736428/document

De Gruyter, C., Currie, G., \& Rose, G. (2016). Sustainability Measures of Urban Public Transport in Cities: A World Review and Focus on the Asia/Middle East Region. Sustainability, 9(1), 43.

https://doi.org/10.3390/su9010043

Díaz-Ramirez, J., Giraldo-Peralta, N., Flórez-Ceron, D., Rangel, V., Mejía-Argueta, C., Huertas, J.I. et al. (2017). Ecodriving key factors that influence fuel consumption in heavy-truck fleets: A Colombian case. Transportation Research Part D: Transport and Environment, 56, 258-270. https://doi.org/10.1016/j.trd.2017.08.012

Domínguez-Caamaño, P., Olmedo, B., Rodríguez-García, M., \& Prado-Prado, J.C. (2017). How to Do Road Transport More Sustainable? A Literature Review. In Closing the Gap Between Practice and Research in Industrial Engineering, 177-184. Cham: Springer. https://doi.org/10.1007/978-3-319-58409-6_20

Eklington, J. (1998). Cannibals with forks: The Triple Bottom Line of the 21st century. Stoney Creek, CT.

Evangelista, P. (2014). Environmental sustainability practices in the transport and logistics service industry: An exploratory case study investigation. Research in Transportation Business \& Management, 12, 63-72.

https://doi.org/10.1016/j.rtbm.2014.10.002

EurObserv'ER (2017). Biofuels Barometer 2017. https://www.eurobserv-er.org/biofuels-barometer-2017 (Accessed: July 2017)

EUROSTAT (2014). Freght transport statistics 2014. http://ec.europa.eu/eurostat/statistics-explained/index.php/Freight_transport_statistics (Accessed: December 2016)

Fercoq, A., Lamouri, S., \& Carbone, V. (2016). Lean/Green integration focused on waste reduction techniques. Journal of Cleaner production, 137, 567-578. https://doi.org/10.1016/j.jclepro.2016.07.107

García-Arca, J., González-Portela-Garrido, \& Prado-Prado, J.C. (2017a). Implementing "Sustainable Packaging Logistics". An analysis in liquid detergents. Dirección y Organización, (60), 47-56.

http://revistadyo.com/index.php/dyo/article/view/498/520

García-Arca, J., González-Portela-Garrido, A., \& Prado-Prado, J.C. (2017b). "Sustainable Packaging Logistics". The link between Sustainability and Competitiveness in Supply Chains. Sustainability, 9(7), 1098.

https://doi.org/10.3390/su9071098 
García-Arca, Prado-Prado \& González-Portela-Garrido (2017). La mejora en la eficiencia y sostenibilidad de la cadena de suministro mediante el diseño del envase y el embalaje. Servizo de Publicación da Universidad de Vigo.

Grant, D.B., Teller, C., \& Teller, W. (2005). Web-based surveys in logistics research: an empirical application. Research Methodologies in Supply Chain Management, 139-154. https://doi.org/10.1007/3-7908-1636-1_10

Gupta, A., Singh, R.K., \& Suri, P.K. (2015). Study of Best Practices and Challenges for Logistics Providers in India. International Journal of Advance Research and Innovation, 3(1), 397-403. http://www.ijari.org/CurrentIssue/ICARI2015/ICARI-ME-15-01-165.pdf

Ho, S.K. (2010). Integrated lean TQM model for global sustainability and competitiveness. The TQM Journal, 22(2), 143-158. https://doi.org/10.1108/17542731011024264

Huber, P., Nerudová, D., \& Rozmahel, P. (2015). Competitiveness, social inclusion and sustainability in a diverse European union. Berlin: Springer.

Iannone, F. (2012). The private and social cost efficiency of port hinterland container distribution through a regional logistics system. Transportation Research Part A: Policy and Practice, 46(9), 1424-1448. https://doi.org/10.1016/j.tra.2012.05.019

Kolosz, B., \& Grant-Muller, S. (2016). Sustainability assessment approaches for intelligent transport systems: the state of the art. IET Intelligent Transport Systems, 10(5), 287-297. https://doi.org/10.1049/iet-its.2015.0025

Kotzab, H. (2005). The role and importance of survey research in the field of supply chain management. Research Methodologies in Supply Chain Management, 125-137. https://doi.org/10.1007/3-7908-1636-1_9

Kotzab, H., Seuring, S., Müller, M., \& Reiner, G. (2005). Research methodologies in supply chain management. Springer Science \& Business Media. https://doi.org/10.1007/3-7908-1636-1

Kudla, N.L., \& Klaas-Wissing, T. (2012). Sustainability in shipper-logistics service provider relationships: A tentative taxonomy based on agency theory and stimulus-response analysis. Journal of Purchasing and Supply Management, 18(4), 218-231. https://doi.org/10.1016/j.pursup.2012.04.001

Mangiaracina, R., Marchet, G., Perotti, S., \& Tumino, A. (2015). A review of the environmental implications of B2C e-commerce: a logistics perspective. International Journal of Physical Distribution \& Logistics Management, 45(6), 565-591. https://doi.org/10.1108/IJPDLM-06-2014-0133

Matopoulos, A., \& Bourlakis, M. (2010). Sustainability practices and indicators in food retail logistics: findings from an exploratory study. Journal on Chain and Network. Science, 10(3), 207-218. https://doi.org/10.3920/JCNS2010.x179

McKinnon, A.C. (2009). Benchmarking Road Freight Transport: review of a government-sponsored programme. Benchmarking: An International Journal, 16(5), 640-656. https://doi.org/10.1108/14635770910987850

McKinnon, A.C., \& Ge, Y. (2006). The potential for reducing empty running by trucks: a retrospective analysis. International Journal of Physical Distribution \& Logistics Management, 36(5), 391-410. https://doi.org/10.1108/09600030610676268

Mohammadi, M., Torabi, S.A., \& Tavakkoli-Moghaddam, R. (2014). Sustainable hub location under mixed uncertainty. Transportation Research Part E: Logistics and Transportation Review, 62, 89-115.

https://doi.org/10.1016/j.tre.2013.12.005

Morali, O., \& Searcy, C. (2013). A review of sustainable supply chain management practices in Canada. Journal of Business Ethics, 117(3), 635-658. https://doi.org/10.1007/s10551-012-1539-4

Oberhofer, P., \& Dieplinger, M. (2014). Sustainability in the transport and logistics sector: lacking environmental measures. Business Strategy and the Environment, 23(4), 236-253. https://doi.org/10.1002/bse.1769

Oglethorpe, D., \& Heron, G. (2010). Sensible operational choices for the climate change agenda. The International Journal of Logistics Management, 21(3), 538-557. https://doi.org/10.1108/09574091011089844 
Pålsson, H., Finnsgård, C., \& Wänström, C. (2013). Selection of packaging systems in supply chains from a sustainability perspective: The case of Volvo. Packaging Technology and Science, 26(5), 289-310.

https://doi.org/10.1002/pts.1979

Piotrowicz, W., \& Cuthbertson, R. (2015). Performance measurement and metrics in supply chains: an exploratory study. International Journal of Productivity and Performance Management, 64(8), 1068-1091. https://doi.org/10.1108/IJPPM-04-2014-0064

Porter, M.E., \& Kramer, M.R. (2006). Strategy and society: The link between competitive advantage and corporate social responsibility. Harvard business review, 84(12), 78-92. https://www.sharedvalue.org/sites/default/files/resource-files/Strategy and Society.pdf

Sedghi, M., Ahmadian, A., \& Aliakbar-Golkar, M. (2016). Assessment of optimization algorithms capability in distribution network planning: Review, comparison and modification techniques. Renewable and Sustainable Energy Reviews, 66, 415-434. https://doi.org/10.1016/j.rser.2016.08.027

Suzuki, Y., \& Kabir, Q.S. (2015). Green Vehicle Routing for Small Motor Carriers. Transportation Journal, 54(2), 186-212. https://muse.jhu.edu/article/581350/pdf https://doi.org/10.5325/transportationj.54.2.0186

UNCTAD (2015). Sustainable freight transport systems: Opportunities for developing countries. http://unctad14.org/EN/pages/NewsDetail.aspx?newsid=32 (Accessed: December 2015)

van Loon, P., Deketele, L., Dewaele, J., McKinnon, A., \& Rutherford, C. (2015). A comparative analysis of carbon emissions from online retailing of fast moving consumer goods. Journal of Cleaner Production, 106, 478-486. https://doi.org/10.1016/j.jclepro.2014.06.060

Wang, Y., Sanchez Rodrigues, V., \& Evans, L. (2015). The use of ICT in road freight transport for $\mathrm{CO}_{2}$ reduction-an exploratory study of UK's grocery retail industry. The International Journal of Logistics Management, 26(1), 2-29. https://doi.org/10.1108/IJLM-02-2013-0021

Wee, H.M., \& Wu, S. (2009). Lean supply chain and its effect on product cost and quality: a case study on Ford Motor Company. Supply Chain Management: An International Journal, 14(5), 335-341. https://doi.org/10.1108/13598540910980242

Journal of Industrial Engineering and Management, 2018 (www.jiem.org)

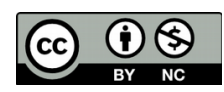

Article's contents are provided on an Attribution-Non Commercial 4.0 Creative commons International License. Readers are allowed to copy, distribute and communicate article's contents, provided the author's and Journal of Industrial Engineering and Management's names are included. It must not be used for commercial purposes. To see the complete license contents, please visit https://creativecommons.org/licenses/by-nc/4.0/. 